- Rezhym dostupu : https://er.knutd.edu.ua/bitstream/123456789/7756/1/20171006_Effect_P169182.pdf

10. Shakhina I. Yu. Vyznachennia i napriamy stvorennia informatsiinoho osvitnoho seredovyshcha [Elektronnyi resurs]. - Rezhym dostupu : http://www.kpi.kharkov.ua/archive/...pdf

Одержано статтю: 11.11 .2018

Прийнято до друку: 5.12.2018

УДК 378.011.3.06-057.87:37:004.5.031.42

DOI: $10.15330 /$ esu. 14.231-238

\author{
Мирослава Томашевська, \\ аспірант, Мукачівський державний університет \\ (м. Мукачево, Україна) \\ Myroslava Tomashevska, \\ Post-graduate student, Mukachevo State University \\ (Mukachevo, Ukraine) \\ mtomashevska@ukr.net
}

Василь Кобаль, кандидат педагогічних наук, доцент, Мукачівський державний університет (м. Мукачево, Україна)

Vasyl Kobal, Candidate of pedagogical sciences, Associate Professor, Mukachevo State University (Mukachevo, Ukraine)

kobalv2008@ukr.net

\title{
ПІДГОТОВКА МАЙБУТНІХ ВИКЛАДАЧІВ ПЕДАГОГІЧНИХ ДИСЦИПЛІН ДО ПРОФЕСІЙНОЇ ВЗАЕМОДІЇ ЗАСОБАМИ ІНТЕРАКТИВНИХ ТЕХНОЛОГІЙ НАВЧАННЯ : МОДЕЛЮВАННЯ ПЕДАГОГТЧНОГО ПРОЦЕСУ
}

\section{THE TRAINING OF FUTURE LECTURERS OF THE PEDAGOGICAL DISCIPLINES FOR PROFESSIONAL INTERACTION BY MEANS OF INTERACTIVE TECHNOLOGIES OF EDUCATION: MODELING OF PEDAGOGICAL PROCESS}

У статті запропоновано та обтрунтовано структурно-функиіональну модель підготовки майбутніх педагогів до професійної взасмодії на рівні “викладач-студент" $з$ використанням інтерактивних технологій навчання. Ключовими компонентами моделі визначено чілепрогностичний (включає мету та завдання), методологічний (розкриває всі методологічні підходи та охоплюе принциити, на яких базується підготовка майбутніх педагогів ЗВО до професійної взаємодіï), змістово-прочесуальний (до иього компонента входять мотивачійний, когнітивно-комунікативний, професійно-рефлексивний складники) та діагностико-результативний (висвітлюе критерії, рівні, показники готовності майбутніх викладачів до професійної взасмодії), які у взасмозв'язку та взасмовпливі забезпечують досягнення бажаного результату - сформовану готовність майбутніх викладачів до професійной взасмодії в умовах магістратури.

Ключові слова: модель, професійна підготовка, педагогічні умови, професійна взаємодія, компоненти, принцити підготовки.

The article presents and substantiates the structural-functional model of the future teachers training to professional interaction at the level of "teacher-student" with the use of interactive learning technologies, since today it is urgent to prepare the future teacher with professionalpedagogical internal motives, orientation which is not just external manifestation, but behavioral character. 
In our study, the concept of "Modeling the future teachers training of pedagogical disciplines for professional interaction by means of interactive learning technologies, " we regard as a project of educational process with masters - future teachers, which includes a system of components that interact and the interaction will achieve the desired result - the formed at the appropriate level, the readiness of future teachers for professional interaction by means of interactive learning technologies in a master's degree.

The key components of the model are goal-oriented (includes the purpose and objectives), the methodological (reveals all methodological approaches and covers the principles on which the training of future educators is for the professional interaction), the content-procedural (this component includes motivational, cognitive-communicative, professional- reflexive components) and diagnostic-productive (highlights criteria, levels, indicators of readiness of future teachers for professional interaction), which are interconnected and mutually beneficial The achievements of the desired result are being achieved - the prepared readiness of future teachers for professional interaction in the conditions of the magistracy.

The directions of further inquiries into this problem we see in the experimental verification of the effectiveness of pedagogical conditions and the model of training future teachers of pedagogical disciplines for professional interaction by means of interactive learning technologies.

Key words: structurally functional model, professional training, pedagogical conditions, professional interaction, components, principles of preparation.

Постановка проблеми. В освітньому середовищі спостерігається традиційна орієнтованість на взаємовідношення між викладачем і студентами, в якій немає усталеної практики, спрямованої на забезпечення професійної взаємодії суб'єктів даного процесу. Однак саме сьогодні все виразніше проявляється інтерес суспільства до проблеми готовності майбутніх викладачів до професійної взаємодії як одного із чинників забезпечення високої якості освітнього процесу у закладах вищої освіти.

Нагальним стає необхідність готувати майбутнього педагога 3 професійнопедагогічними внутрішніми мотивами, спрямованістю, які мають не просто зовнішній прояв, а поведінковий характер.

Саме тому актуальність професійної підготовки набуває важливого значення, оскільки вона має бути спрямована на формування особистості, яка володіє не тільки системою спеціальних знань та професійних умінь, а й вирізняється сформованістю професійно важливих компетентностей, відповідним рівнем кваліфікації 3 урахуванням світових і європейських стандартів якості при збереженні національних здобутків і пріоритетів, а також здатної до плідної викладацької діяльності.

Отже, проблема підготовки майбутніх викладачів до професійної взаємодії на рівні “викладач-студент" набуває все більшої значущості. Саме тому, для реалізації мети, завдань та концептуальних засад нашого дослідження виникла необхідність у розробці моделі процесу підготовки майбутніх викладачів до професійної взаємодії.

Аналіз останніх досліджень i публікацій. Моделювання в наукових дослідженнях, яке почали застосовувати ще в глибоку давнину, охоплює сьогодні все нові сфери наукових знань. Проблемі розробки моделі фахівців присвячено дослідження багатьох науковців, зокрема: І. Зазюна, В. Сластьоніна, Н. Кузьміної, I. Козич, I. Беха, А. Вербицького, С. Сисоєвої, А. Маркової, О. Романовського, В. Ягупова, В. Семиченко, О. Мармази, В. Маслова та ін.

Ю. Бабанський, Н. Кузьміна у своїх дослідженнях обгрунтували різні підходи до моделювання і приділили увагу важливості використання цього методу у вивченні освітніх процесів. Дослідники відзначають, що метод моделювання полягає 
“...у теоретичній побудові моделей педагогічних явищ у “чистому вигляді”, звільнених від емпіричної основи” [1].

Шляхи професійної підготовки педагогів вищої школи, теоретичні та методичні засади формування професіоналізму, професійної культури, професійної майстерності та власне професійної компетентності викладачів закладів вищої освіти розкриваються в працях В. Андрущенка, О. Браславської, В. Бондаря, В. Коваля, В. Майбороди та ін.

Проте у наукових працях учених не достатньо висвітлено проблему вдосконалення процесу підготовки майбутніх педагогів до професійної взаємодії в умовах магістратури.

Саме тому, метою статті $є$ розробка та теоретичне обгрунтування моделі підготовки майбутніх викладачів педагогічних дисциплін до професійної взаємодії засобами інтерактивних технологій навчання.

Виклад основного матеріалу дослідження. Для вирішення поставленої мети нашого дослідження доцільно буде розглянути такі категорії: модель, моделювання.

Модель (з лат. Modus - міра, франц. modele - зразок, еталон, стандарт) у теорії пізнання тлумачиться як штучно створений об'єкт у вигляді схеми, креслення, математичних знаків, формул тощо, який $€$ аналогом, замінником об'єкта, що досліджується й відтворює в більш простому, зменшеному вигляді структуру, властивості, взаємозв'язки та стосунки між елементами досліджуваного об’єкта [4, с. 276].

Великий тлумачний словник української мови термін “модель” розглядає як уявну або матеріально реалізовану систему, що відображає, відтворює або імітує будову i дію певного об’єкта дослідження (природного чи соціального), використовується для одержання нових знань про нього [4].

I. Межуєва у своєму дослідженні розкриває поняття "модель" наступним чином: "відкрита розвиваюча система, забезпечуючи можливість гнучкої зміни їі структури і власних параметрів у міру накопичування нової інформації і зміни потреб практики та соціального замовлення суспільства" [7].

У нашому дослідженні ми опираємося на доробки О. Лавріненка, який зауважує, що метод педагогічного моделювання переважно використовується для точності опису та визначення педагогічних об'єктів, розробки педагогічних конструктів та має такі етапи:

1) концептуальне моделювання (розробка концептуальної моделі формування вмінь, розвитку якостей особистості тощо);

2) системне моделювання (розробка системи взаємопов'язаних між собою моделей різних видів педагогічних об'єктів);

3) процесуальне моделювання (відбувається відображення динаміки та логіки розвитку досліджуваного об'єкта);

4) праксеологічне моделювання (безпосередньо модель практичного результату дій педагога або його взаємодіi) [6, с. 326].

До змісту педагогічної моделі в дослідженні А. Кочергіна висунуто такі вимоги:

1. Дидактичні (доцільність, значущість змісту, динамічність розвитку змісту, раціональність побудови інформаційної моделі).

2. Методичні (наявність логіки і структури у відображенні змісту; відповідність обсягу інформації умовам оптимального функціонування пам'яті (перевантаження або недовантаження); естетичність і художність відображення змісту; зв’язок змісту з алгоритмом заходів, що проводяться). 
3. Технічні (варіативність темпу подачі інформації сучасність засобів відображення змісту; зручність управління заходами, які проводяться) [8, с. 5-7].

Процес формування професійних відносин викладачів і студентів у закладах вищої освіти $\epsilon$ інноваційним, оскільки містить значущі 3 точки зору вирішуваних завдань елементи новизни. Для побудови цього процесу необхідно його моделювання, оскільки саме моделювання дає цілісність подання і сприйняття інформації про той чи інший об'єкт. Моделювання $\epsilon$ необхідною процедурою при конструюванні педагогічних процесів 3 широким спектром завдань. У загальнонауковому аспекті під моделлю розуміється “створена або вибрана суб”єктом система, яка відтворює суттєві для даної цілі пізнання компоненти (елементи, властивості, відносини, параметри) досліджуваного об'єкта"' [2].

Ю. Шабанова у своїх дослідженнях поняття “модель" трактує як систему, яка відтворює об'єкт дослідження і здатна замінювати його так, що вивчення цієї системи дає нам нову інформацію про об'єкт. Моделювання дає змогу наочно уявити об'єкт, проникнути в його глибину, розпізнати складові елементи й описати важливі теоретичні питання досліджуваної проблеми. [9, с. 120].

Отже, проаналізувавши дані визначення науковцями та дослідниками маємо можливість зробити такі узагальнення: системоутворювальним чинником понять "модель", “педагогічне моделювання" $є$ педагогічна реальність яку моделюють система, реальність, модель як образ цієї реальності - система-модель і суб’єкт моделювання (педагог, дослідник) - система, що моделює. Проте модель в освітньому процесі - це не лише відображення деякого стану педагогічної реальності, але й “форма діяльності, якою передбачається репрезентація майбутньої практики і засвоєних форм діяльності” [3, с. 506].

У нашому дослідженні поняття "Модель підготовки майбутніх викладачів педагогічних дисциплін до професійної взаємодії засобами інтерактивних технологій навчання" (далі - Модель) ми розглядаємо як проект освітнього процесу 3 магістрами - майбутніми викладачами, який включає систему компонентів, які у взаємозв'язку та взаємовпливі будуть давати досягнення бажаного результату сформовану на належному рівні готовність майбутніх педагогів до професійної взаємодії засобами інтерактивних технологій навчання в умовах магістратури.

Для кращого розуміння даного процесу ми пропонуємо побудувати модель підготовки до професійної взаємодії на рівні “викладач-магістрант”, яка складатиметься iз 4 компонентів: цілепрогностичного, методологічного, змістовопроцесуального, діагностико-результативного (рис. 1).

Цілепрогностичний компонент Моделі повність відтворює іiі мету забезпечення формування готовності майбутніх викладачів педагогічних дисциплін до професійної взаємодії із застосуванням інтерактивних технологій навчання. Цілі даної моделі координуються з метою даного дослідження - формування особистості, забезпечення його професійного розвитку, професійної компетентності, професійна допомога і співпраця у розкритті професійно значущих якостей та обов'язкових умінь до здійснення наукової діяльності.

Отже, перший компонент включає в себе постановку цілей і прогнозування результатів зі створення єдиного простору взаєморозуміння позицій. 


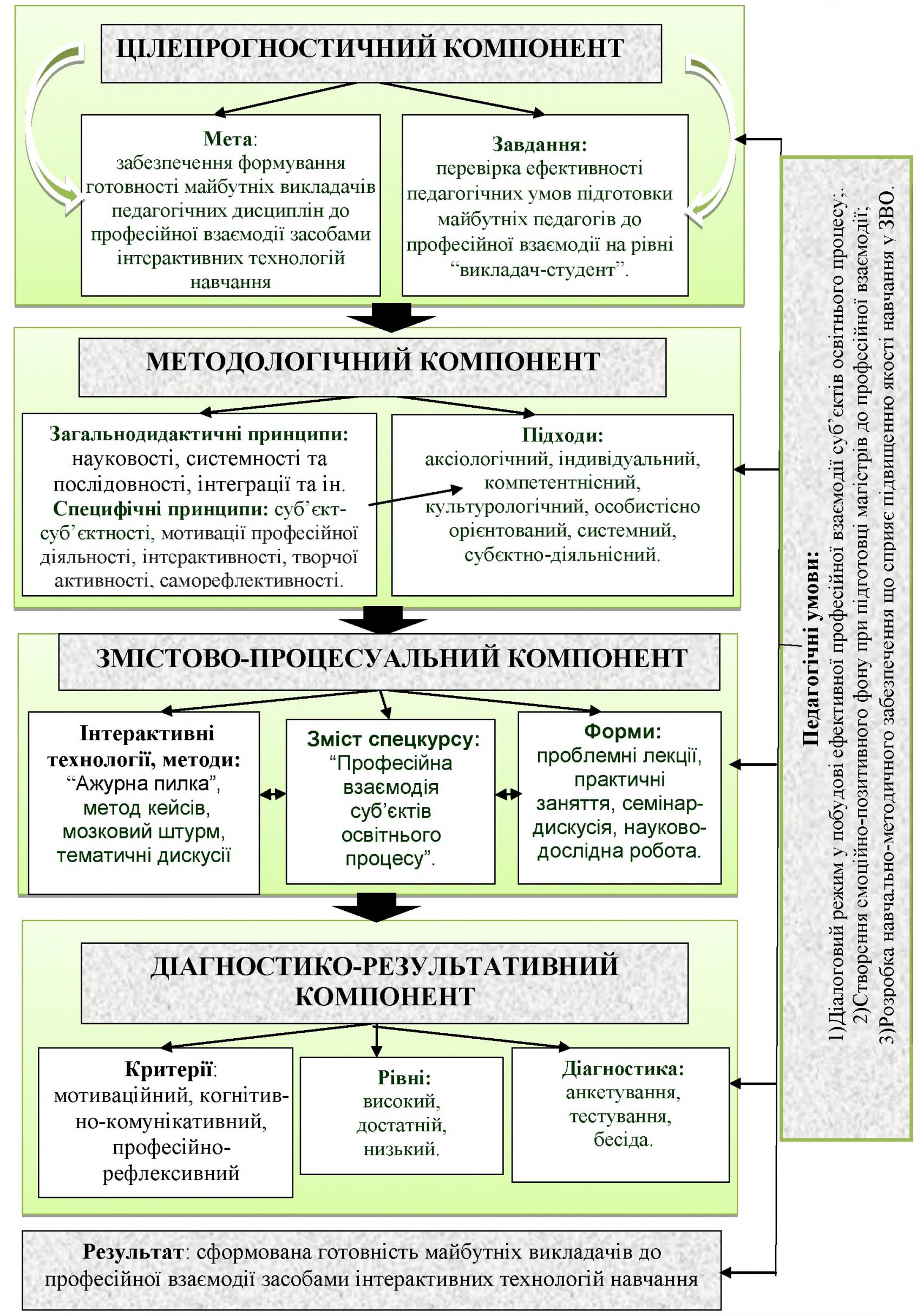

Pис. 1. Модель підготовки майбутніх викладачів педагогічних дисииплін до професійної взаємодії засобами інтерактивних технологій навчання 
Методологічний компонент охоплює всі методологічні підходи, принципи, які забезпечують формування готовності майбутніх педагогів закладів вищої освіти до професійної взаємодії в умовах магістратури, а саме: аксіологічний, індивідуальний, компетентнісний, культурологічний, особистісно орієнтований, системний, суб'єктно-діяльнісний підходи.

Застосування основних положень можливе лише завдяки використанню загальнодидактичних та специфічних принципів навчання. Систему загальнодидактичних принципів становлять принцип науковості, системності та послідовності, кооперативності, інтеграції, доступності, фундаменталізації, індивідуалізації.

У поєднанні із загальнодидактичними застосовуються специфічні принципи, які є основними в нашому дослідженні: принцип суб'єкт-суб'єктності, принцип мотивації професійної діяльності, принцип інтерактивності, принцип діяльнісного навчання, принцип варіативності педагогічної освіти, принцип творчої активності викладача, принцип саморефлексивності.

До змістово-технологічного компоненту моделі готовності майбутніх викладачів до професійної взаємодії ми включили мотиваційний, когнітивнокомунікативний, професійно-рефлексивний складники, які реалізовані у спецкурсі “Професійна взаємодія суб'єктів освітнього процесу”; форми і методи формування готовності майбутніх викладачів $3 \mathrm{BO}$ до професійної взаємодії засобами інтерактивних технологій навчання.

Діагностико-аналітичний компонент розкриває критерії та рівні сформованості готовності майбутніх викладачів до професійної взаємодії. Цей етап $є$ логічним завершенням підготовки майбутніх викладачів до професійної взаємодії на рівні “викладач - студент-магістрант" в освітньому процесі закладу вищої освіти i включає активність викладачів і студентів в аналізі, самоаналізі та оцінці отриманого результату; самоаналіз; взаємну задоволеність ходом і результатом взаємодії.

Реалізація моделі підготовки майбутніх викладачів педагогічних дисциплін до професійної взаємодії засобами інтерактивних технологій навчання здійснюється через спільну взаємодію всіх компонентів при впровадженні їх у процес підготовки майбутніх викладачів до професійної взаємодії 3 дотриманням визначених педагогічних умов, а саме:

- діалоговий режим у побудові ефективної професійної взаємодії суб’єктів освітнього процесу на рівні “викладач - студент-магістрант";

- створення емоційно-позитивного фону при підготовці магістрантів до професійної взаємодії на рівні “викладач-магістрант”; створення "ситуації успіху”;

- розробка навчально-методичного забезпечення, що сприяє підвищенню якості навчання у ЗВО, застосування таких технологій і методів навчання, коли студент може зайняти активну особистісну позицію і в повній мірі проявити себе як суб’єкт навчальної діяльності, а також професійно взаємодіяти 3 викладачем на заняттях.

Складовою Моделі нашого дослідження $є$ методи навчання, що використовуються на всіх етапах професійної взаємодії викладачів і студентів, серед яких переважають інтерактивні, а саме: диспут, дебати, метод кейсів, тематичні дискусії, “мозковий штурм", моделювання проблемних ситуацій, метод “Ажурна пилка", круглі столи, рольові ігри, “Акваріум", “Ланцюжок”, бліц-турнір тощо.

Ефективність компонентів процесу вдосконалення готовності майбутніх педагогів до професійної взаємодії забезпечувалася з урахуванням і реалізацією виявлених i обгрунтованих у дослідженні педагогічних умов. Очевидно, що 
прогнозований результат апробації Моделі - сформована готовність майбутнього викладача педагогічних дисциплін до професійної взаємодії в цілому визначається, 3 одного боку, високим рівнем опрацьованості й узагальнення елементів моделі, 3 іншого - оптимальними зв'язками і відносинами між ними (елементами) - коли кожен елемент Моделі, реалізуючи свої основні функції, продуктивно впливас на всі інші елементи і відповідно сам збагачується новими характеристиками.

Такий взаємозв'язок і взаємовплив елементів дозволяє в сукупності проявів досягти мети i завдань функціонування Моделі і тим самим підтвердити іii ефективність.

Висновки i перспективи подальших наукових розвідок. Розроблена структурно-функціональна модель підготовки майбутніх викладачів педагогічних дисциплін до професійної взаємодії засобами інтерактивних технологій навчання $\epsilon$ теоретичною конструкцією, яка включає в себе мету, завдання, методологічні підходи, наукові принципи, зміст навчання, форми, методи навчання тощо.

Напрямами подальших розвідок з даної проблеми ми вбачаємо в експериментальній перевірці ефективності педагогічних умов та Моделі підготовки майбутніх викладачів педагогічних дисциплін до професійної взаємодії засобами інтерактивних технологій навчання.

\section{Література}

1. Бабанский Ю. К. Методы обучения в современной общеобразовательной школе / Ю. К. Бабанский. - М.: Просвещение, $1985 .-208$ с.

2. Белозерцев Е.П. Гуманистические основания педагогической подготовки учителя / Е.П.Белозерцев // Гуманизация образования. - 1994 - №2. - С. 34-42.

3. Вартофской М. Модели. Репрезентация и научное понимание / М.Вартофской. - М. : Прогрес, 1998. $-506 \mathrm{c}$.

4. Великий тлумачний словник сучасної української мови / упоряд. і гол. ред. В. Т. Бусел. К.; Ірпінь: ВТФ "Перун”, 2009. - 1736 с.

5. Гончаренко С.У. Український педагогічний словник / С.У. Гончаренко. - К. : Либідь, 1997 $376 \mathrm{c}$.

6. Лавріненко О. А. Педагогічна майстерність в історико-педагогічному вимірі: теорія, практика, поступ : монографія. - К. : Богданова А., 2009. - 328 c.

7. Межуєва І. Ю. Розвиток творчої активності студентів немовного ВНЗ у процесі моделювання іншомовної предметної діяльності майбутнього фахівця : автореф. дис. ... канд. пед. наук : 13.00.04 "Теорія і методика професійної освіти"/ І Ю. Межуєва. - Тула, 2004. - 23 с.

8. Кочергин А. Н. Моделирование мышления / А. Н. Кочергин. - М. Политиздат, 1969. - 224 с

9. Шабанова Ю.О. Системний підхід у вашій школі: підруч. для студ. магістратури / Ю.О. Шабанова. - Д: НГУ, 2014. - 120 c.

\section{References}

1. Babanskyi Yu. K. Metodi obuchenyia v sovremennoi obshcheobrazovatelnoi shkole / Y.K. Babanskyi. - M. : Prosveshchenye, 1985. - 208 s.

2. Belozertsev E.P. Humanystycheskye osnovanyia pedahohycheskoi podhotovky uchytelia // Humanyzatsyia obrazovanyia. - 1994. - №2. - S.34-42.

3. Vartofskoi M. Modely. Reprezentatsyia y nauchnoe ponymanye / M.Vartofskoi. - M. : Prohress, 1998. $-506 \mathrm{~s}$.

4. Velykyi tlumachnyi slovnyk suchasnoi ukrainskoi movy / uporiad. i hol. red. V. T. Busel. K.; Irpin: VTF "Perun", 2009. - $1736 \mathrm{~s}$.

5. Honcharenko S.U. Ukrainskyi pedahohichnyi slovnyk / S.U. Honcharenko. - K. : Lybid, 1997. - 376 s.

6. Lavrinenko O. A. Pedahohichna maisternist $v$ istoryko-pedahohichnomu vymiri: teoriia, praktyka, postup: monohrafiia. K.: Bohdanova A. - 2009. $-328 \mathrm{~s}$.

7. Mezhuieva I. Yu. Rozvytok tvorchoi aktyvnosti studentiv nemovnoho VNZ u protsesi modeliuvannia inshomovnoi predmetnoi diialnosti maibutnoho fakhivtsia : avtoref. dys. ... kand. ped. nauk : 13.00.04 "Teoriia i metodyka profesiinoi osvity"/ I. Yu. Mezhuieva. - Tula, 2004. - 23 s. 
8. Kocherhyn A. N. Modelyrovanye myshlenyia / A. N. Kocherhyn. - M. : Polytyzdat, 1969. - 224 s.

9. Shabanova Yu.O. Systemnyi pidkhid u vashii shkoli: pidruch. dlia stud. mahistratury / Yu.O. Shabanova. - D.: NHU, 2014. $-120 \mathrm{~s}$.

Одержано статтю: 1.11 .2018

Прийнято до друку: 25.11.2018

УДК: $378.1+37.01$

DOI: $10.15330 /$ esu. $14.238-244$

\section{Іскендер Топчу,}

аспірант, Державний педагогічний університет імені Іона Крянге (м. Кишинів, Молдова)

Iskender Topchu,

Post-graduate student,

"Ion Creangă" State Pedagogical University of

Chisinau (Chisinau, Moldova)

catedrapsihologie@gmail.com

\section{ФОРМИРОВАНИЕ КОММУНИКАТИВНЫХ КОМПЕТЕНЦИЙ УЧЕНИКОВ СРЕДСТВАМИ ИГРОВЫХ СИТУАЦИЙ}

\section{THE FORMING OF COMMUNICATIVE COMPETENCES OF PUPILS BY MEANS OF GAME SITUATIONS}

У статті проаналізовано роль ігрових ситуачій у прочесі формування комунікативних компетениій учнів. Визначено, ияо в умовах сучасної иколи традииійний підхід до навчання не забезпечуе в повній мірі інтенсивне оволодіння необхідною системою знань. Використання системи ігрових ситуачій дозволяе ефективно формувати, вдосконалювати і розвивати навички та вміния усіх видів мовної діяльності. Ігрові вправи, які використовуються систематично, сприяють моделюванню умов реального спілкування в прочесі навчання, ио, в свою чергу, призводить до підвищения рівня мотивачії вивчення іноземної мови.

Ключові слова: ігрові ситуачій, мовна діяльність, комунікативні компетенції.

The article analyzes the role of gaming situations in the process of forming communicative competences of students. It is determined that in the conditions of a modern school, the traditional approach to teaching does not fully ensure the intensive mastery of the necessary knowledge system. The use of the game situation system allows you to effectively shape, improve and develop the skills and abilities of all types of language activities. The game exercises, which are used systematically, help to model the conditions of real communication in the learning process, which in turn leads to an increase in the level of motivation for learning a foreign language.

The situation as a relationship system is not born arbitrarily. Students can be given specific situational positions, the situation itself will arise and will function on their basis, and this, with controlled training, allows you to plan the necessary situations in advance. The situation is a universal form of the functioning of the communication process, existing as an integrative dynamic system of social status, role, activity and moral relations between the subjects of communication, reflected in their minds and arising from the interaction of the situational positions of those communicating.

Game situations in foreign language lessons in the context of our study, we have determined, based on the structure of activity, as an active type of educational activity on simulation modeling of the systems, processes and phenomena that are studied.

Game exercises with an element of competition provide motivation for learning and speech activities due to participation in game activities. Game situations with a role-based component contribute to enhancing the motivation of student participation in foreign language communication in the classroom and the formation of student communication skills. Game 